\title{
Early development of histiocytic sarcomas in p53 knockout mice treated with $\mathbf{N}$-bis(2-hydroxypropyl)nitrosamine
}

\author{
AKIHIRO HIRATA ${ }^{1,2}$, TETSUYA TSUKAMOTO ${ }^{1}$, MASAMI YAMAMOTO $^{1}$, SHINJI TAKASU $^{1,3}$, \\ HIROKI SAKAI $^{1,3}$, HISAYO BAN ${ }^{1}$, TOKUMA YANAI ${ }^{3}$, TOSHIAKI MASEGI ${ }^{3}$, \\ LAWRENCE A. DONEHOWER ${ }^{4}$ and MASAE TATEMATSU ${ }^{1}$
}

\begin{abstract}
${ }^{1}$ Division of Oncological Pathology, Aichi Cancer Center Research Institute, 1-1 Kanokoden, Chikusa-ku, Nagoya 464-8681;
${ }^{2}$ Division of Animal Experimentation, Life Science Research Center, Gifu University, 1-1 Yanagido, Gifu 501-1194;

${ }^{3}$ Department of Veterinary Pathology, Gifu University, 1-1 Yanagido, Gifu 501-1193, Japan; ${ }^{4}$ Department of Molecular Virology and Microbiology, Baylor College of Medicine, Houston, TX 77030, USA
\end{abstract}

Received April 12, 2007; Accepted June 28, 2007

\begin{abstract}
. p53 knockout mice have been utilized for the functional analysis of p53 in carcinogenic processes and for the evaluation of the carcinogenic potential of chemicals. In this study, we established that p53 knockout mice have an elevated susceptibility to the induction of histiocytic sarcoma (HS) by $\mathrm{N}$-bis(2-hydroxy-propyl)nitrosamine (BHP). p53 heterozygous $(+/-)$ and wild-type $(+/+)$ mice were treated with 20 or $200 \mathrm{ppm}$ BHP in their drinking water for 15 weeks or with 20 ppm BHP for 40 weeks. An additional group of p53 nullizygous (-/-) mice were treated with 20 ppm BHP for 15 weeks. In a 15week experiment, hepatic HSs were unexpectedly observed in BHP-treated p53 (-/-) mice $(30.8 \%)$ but not in p53 (+/-) and $(+/+)$ mice and untreated (-/-) mice, indicating that a complete loss of p53 dramatically accelerates the genesis of HS. In a 40-week experiment, HSs were significantly increased in female p53 (+/-) mice $(37.5 \%)$ as compared with female $(+/+)$ mice $(5.0 \%)$. Additionally, PCR-SSCP and sequencing analysis revealed a high frequency of p53 gene mutations in HSs, demonstrating the involvement of p53 gene mutations in HS development. Our data add to the understanding of the carcinogenic susceptibility of p53 knockout mice, and may help to elucidate the pathogenesis of HS development.
\end{abstract}

\section{Introduction}

The tumor suppressor p53 plays a critical role in preventing the accumulation of the multiple genetic changes involved in tumor development (1). p53 knockout mice, first established

Correspondence to: Dr Tetsuya Tsukamoto, Division of Oncological Pathology, Aichi Cancer Center Research Institute, 1-1 Kanokoden, Chikusa-ku, Nagoya 464-8681, Japan

E-mail: ttsukamt@aichi-cc.jp

Key words: p53 knockout mouse, histiocytic sarcoma, N-bis(2hydroxypropyl)nitrosamine, liver, p53 mutation by Donehower et al (2), have been utilized for the functional analysis of p53 in carcinogenic processes and, additionally, for the evaluation of the carcinogenic potential of chemicals (3).

Histiocytic sarcoma (HS) is classified as a non-lymphoid hematopoietic neoplasm (4) and is thought, based on its immunohistochemical and ultrastructural features, to be derived from cells of mononuclear phagocyte lineage $(5,6)$. It is a rare, spontaneous tumor in mice; at 24 months of age, incidences of it in common strains are between 0 and $5.5 \%$ $(4,7)$. However, more frequent development has been reported in genetically engineered mice (8-12). It is noteworthy that this is also the case in animals with p53-related alterations. For example, it was reported that HS is the most common spontaneous tumor in $\mathrm{p} 21$-deficient mice, accounting for approximately half of all the lesions which develop (8). Loss of BAX alters the tumor spectrum in ARF-deficient mice and results in the emergence of HS (10). Using double-mutant mice, it was also demonstrated that coincident loss of ARF, a regulator of the p53 pathway, with INK4A and PTEN induced the development of HS (12). However, the relevance of p53 itself to HS development has remained unclear. Spontaneous development of HS has not been reported in p53 knockout mice, either in nullizygotes $[\mathrm{p} 53(-/-)]$ or heterozygotess [p53 (+/-)], though they show markedly enhanced genesis of tumors of various types $(2,13-18)$. The mechanisms underlying HS development are poorly understood, so it would appear that studies using genetically engineered mice are warranted.

$\mathrm{N}$-bis(2-hydroxypropyl)nitrosamine (BHP) is a multi-organ genotoxic carcinogen in rodents, whose oral administration induces both lung and hepatic vascular tumors in mice (19). We previously reported on the carcinogenicity of BHP in p53 knockout mice, with a particular focus on differences in susceptibility with reference to lung and hepatic vascular tumors (20). BHP also rapidly induced HS in the livers of p53 nullizygous (-/-) and heterozygous (+/-) mice, though it was not expected that histiocytic cells would be the targets of this carcinogen. We therefore further investigated, in this study, HS development in BHP-treated p53 knockout mice, with a focus on the molecular mechanisms linked to p53 gene alteration. 
Table I. PCR primers for genotyping and for SSCP analysis of mouse p53.

\begin{tabular}{|c|c|c|c|}
\hline Target & & Primer sequence & Product length (bp) \\
\hline \multicolumn{4}{|l|}{ Genotype } \\
\hline \multirow[t]{2}{*}{ Wild-type } & 10681 & 5'-GTGTTTCATTAGTTCCCCACCTTGAC-3' & 320 \\
\hline & 10480 & 5'-ATGGGAGGCTGCCAGTCCTAACCC-3' & \\
\hline \multirow[t]{2}{*}{ Mutant } & 10588 & 5'-GTGGGAGGGACAAAAGTTCGAGGCC-3' & 150 \\
\hline & 10930 & 5'-TTTACGGAGCCCTGGCGCTCGATGT-3' & \\
\hline \multicolumn{4}{|l|}{ PCR-SSCP } \\
\hline \multirow[t]{2}{*}{ Exon 5} & Sense & 5'-TCTCTTCCAGTACTCTCCTC-3' & 214 \\
\hline & Antisense & 5'-AGGCGGTGTTGAGGGCTTA-3' & \\
\hline \multirow[t]{2}{*}{ Exon 6} & Sense & 5'-GGCTTCTGACTTATTCTTGC-3' & 181 \\
\hline & Antisense & 5'-CAACTGTCTCTAAGACGCAC-3' & \\
\hline \multirow[t]{2}{*}{ Exon 7} & Sense & 5'-TCACCTGGATCCTGTGTCTT-3' & 170 \\
\hline & Antisense & 5'-CAGGCTAACCTAACCTACCA-3' & \\
\hline \multirow[t]{2}{*}{ Exon 8} & Sense & 5'-ACTGCCTTGTGCTGGTCCTT-3' & 279 \\
\hline & Antisense & 5'-GGAGAGGCGCTTGTGCAGGT-3' & \\
\hline
\end{tabular}

\section{Materials and methods}

Animals. p53 knockout mice produced by Donehower et al (2) were backcrossed to C57BL/6J (N4) and maintained at the Animal Facility of Aichi Cancer Center Research Institute. Five-week-old males and females were used in the present experiment. They were housed at a maximum of 5 per plastic cage on wood chips in an air-conditioned room with a 12-h light-dark cycle, and given a basal diet (Oriental NMF, Oriental Yeast, Tokyo, Japan) and drinking water ad libitum. Genotyping of each mouse was performed by PCR using 2 sets of primers (Table I), basically as previously described (21).

Experimental design. The experimental design is shown in Fig. 1. BHP (Nacalai Tesque, Kyoto, Japan) was dissolved in distilled water and freshly prepared two times per week. In experiment I, male and female p53 (+/+) and (+/-) mice were given drinking water ad libitum containing 20 or 200 ppm BHP in light-shielded bottles for 15 weeks. An additional group of p53 (-/-) male mice were treated with only 20 ppm for 15 weeks. In experiment II, long-term observation was performed using male and female p53 (+/+) and (+/-) mice that were given drinking water containing $20 \mathrm{ppm}$ BHP for 40 weeks. As controls, matching numbers of mice of each genotype were given distilled water for the same period of time. Necropsies were performed on all animals that died or were sacrificed when they became moribund. Data for these were not included in experiment I, but, in experiment II, the mice were considered as effective animals when prematurely sacrificed as moribund after experimental week 36. At the end of the experiment, all surviving mice were sacrificed and autopsied.

Histopathological analysis. Tissues were fixed in $4 \%$ paraformaldehyde in $0.1 \mathrm{M}$ phosphate buffer and were routinely

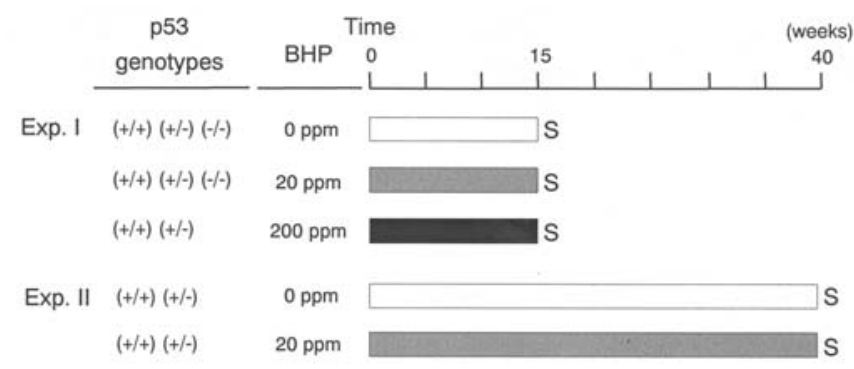

Figure 1. Experimental design. In experiment I, male and female p53 (+/+), $(+/-)$ and male $(-/-)$ mice were used. In experiment II, animals were $(+/+)$ and (+/-) mice of both sexes. BHP at 20 (gray bar) or 200 (closed bar) ppm and water (open bar) as a control were given. Exp., experiment; BHP, Nbis(2-hydroxypropyl)nitrosamine; S, sacrifice.

processed to sections stained with hematoxylin and eosin (H\&E). For the differential diagnosis of HS and lymphoma, the following immunohistochemical markers were used: rabbit anti-human CD3 polyclonal antibody (Dako Japan, Kyoto, Japan) for T-lymphocyte; rat anti-mouse CD45R/ B220 monoclonal antibody (Pharmingen, San Diego, CA) for B-lymphocyte; and rat anti-mouse F4/80 monoclonal antibody (Serotec, Oxford, UK) for monocyte/macrophage detection. A standard avidin-biotin technique (Vectastain ABC kit, Vector Laboratories, Burlingame, CA) was employed with diaminobenzidine as the chromogen. Sections were counterstained with Meyer's hematoxylin to aid orientation.

Analysis of p53 gene alterations. Twelve hepatic HSs from BHP-treated p53 knockout mice, 2 from p53 (+/+) and 10 from (+/-) mice, were subjected to analysis of p53 gene alterations. In order to detect the loss of heterozygosity ( $\mathrm{LOH})$ of the p53 gene in the lesions of p53 (+/-) mice, PCR was 
Table II. Incidence of histiocytic sarcoma.

\begin{tabular}{|c|c|c|c|c|c|c|c|c|c|}
\hline \multirow{2}{*}{$\begin{array}{l}\text { Experimental } \\
\text { period }\end{array}$} & \multirow[b]{2}{*}{ Sex } & \multirow{2}{*}{$\begin{array}{l}\text { BHP } \\
(\mathrm{ppm})\end{array}$} & \multirow{2}{*}{$\begin{array}{c}\text { p53 } \\
\text { genotypes }\end{array}$} & \multicolumn{3}{|c|}{ No. of animals } & \multicolumn{3}{|c|}{ No. of mice with tumors $(\%)$} \\
\hline & & & & Initial & Survival & Effective & Liver & Spleen & Lung \\
\hline \multirow{14}{*}{$\begin{array}{l}\text { Exp. I } \\
\text { (15 weeks) }\end{array}$} & \multirow[t]{8}{*}{ Male } & \multirow[t]{3}{*}{0} & $+/+$ & 20 & 20 & 20 & 0 & 0 & 0 \\
\hline & & & $+/-$ & 20 & $19^{\mathrm{e}}$ & 19 & 0 & 0 & 0 \\
\hline & & & $-/-$ & 20 & $17^{\mathrm{f}}$ & 17 & 0 & 0 & 0 \\
\hline & & \multirow[t]{3}{*}{20} & $+/+$ & 32 & 32 & 32 & 0 & 0 & 0 \\
\hline & & & $+/-$ & 32 & 32 & 32 & 0 & 0 & 0 \\
\hline & & & $-/-$ & 41 & $26^{\mathrm{g}}$ & 26 & $8(30.8)^{\mathrm{a}}$ & $3(11.5)$ & $2(7.7)$ \\
\hline & & \multirow[t]{2}{*}{200} & $+/+$ & 20 & 20 & 20 & 0 & 0 & 0 \\
\hline & & & $+/-$ & 28 & $16^{\mathrm{h}}$ & 16 & 0 & 0 & 0 \\
\hline & \multirow[t]{6}{*}{ Female } & \multirow[t]{2}{*}{0} & $+/+$ & 20 & 20 & 20 & 0 & 0 & 0 \\
\hline & & & $+/-$ & 20 & 20 & 20 & 0 & 0 & 0 \\
\hline & & \multirow[t]{2}{*}{20} & $+/+$ & 32 & 32 & 32 & 0 & 0 & 0 \\
\hline & & & $+/-$ & 32 & 32 & 32 & 0 & 0 & 0 \\
\hline & & \multirow[t]{2}{*}{200} & $+/+$ & 20 & 20 & 20 & 0 & 0 & 0 \\
\hline & & & $+/-$ & 29 & $15^{\mathrm{i}}$ & 15 & 0 & 0 & 0 \\
\hline \multirow{8}{*}{$\begin{array}{l}\text { Exp. II } \\
(40 \text { weeks) }\end{array}$} & \multirow[t]{4}{*}{ Male } & \multirow[t]{2}{*}{0} & $+/+$ & 20 & 20 & 20 & 0 & 0 & 0 \\
\hline & & & $+/-$ & 20 & $19^{j}$ & 19 & 0 & 0 & 0 \\
\hline & & \multirow[t]{2}{*}{20} & $+/+$ & 20 & $19^{\mathrm{k}}$ & 19 & 0 & 0 & 0 \\
\hline & & & $+/-$ & 20 & $14^{1}$ & $17^{\mathrm{c}}$ & $2(11.8)$ & 0 & 0 \\
\hline & \multirow[t]{4}{*}{ Female } & \multirow[t]{2}{*}{0} & $+/+$ & 20 & $19^{\mathrm{m}}$ & 19 & 0 & 0 & 0 \\
\hline & & & $+/-$ & 20 & 20 & 20 & 0 & 0 & 0 \\
\hline & & \multirow[t]{2}{*}{20} & $+/+$ & 20 & 20 & 20 & $1 \quad(5.0)$ & 0 & 0 \\
\hline & & & $+/-$ & 20 & $15^{\mathrm{n}}$ & $16^{\mathrm{d}}$ & $6(37.5)^{b}$ & 0 & 0 \\
\hline
\end{tabular}

${ }^{a}$ Significantly different from male $20 \mathrm{ppm}$ BHP-treated p53 (+/+) and (+/-) mice and control p53 (-/-) mice using the Fisher's exact test,

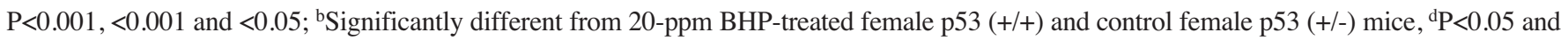
${ }^{\mathrm{e}} \mathrm{P}<0.005$; ' $\mathrm{C}$ ata from three mice sacrificed at experimental week 38 and 39 were included; ${ }^{\mathrm{d}} \mathrm{Data}$ from one mouse sacrificed at experimental week 37 was included; ' Cause of death was lymphoma; ${ }^{\text {TT }}$ The deaths included one from fibrosarcoma, one from malignant fibrous histiocytoma and one from hydrocephalus; ' ${ }^{\text {The }} 15$ deaths included eight from lymphomas, three from sarcomas, one from malignant fibrous histiocytoma and one of unknown cases; h The 12 deaths included ten from hepatic hemangiosarcomas and two of unknown causes; ${ }^{i}$ The causes of all of fourteen deaths were hepatic hemangiosarcomas; ${ }^{\mathrm{j}, \mathrm{k}}$ Causes of deaths were not determined; 'Three moribund mice were sacrificed at experimental weeks 38 and 39. Cause of deaths of the other three mice was lymphoma development; ${ }^{\mathrm{m}}$ The cause of the death was a carcinoma; ${ }^{n}$ One moribund mouse was sacrificed at week 37. The deaths of the other four mice included hepatic histiocytic sarcoma, lymphoma, hemangio sarcoma and one unknown cause.

performed to specifically amplify the wild or mutant allele with PCR primers for the genotyping of mice (Table I). PCRsingle strand conformation polymorphism (SSCP) analysis was conducted basically as previously described (21). The four pairs of primers applied for mouse p53 exons 5-8 are listed in Table I. The primers for exon 5 were designed to specifically amplify the wild-type allele. Abnormal bands, separated by electrophoresis, were excised from the gels and subjected to sequencing analysis utilizing an ABI PRISM 3100 with a BigDye Terminator v3.1 Cycle Sequencing Ready Kit (Applied Biosystems, Forester City, CA). For tumor samples with p53 mutations at exons 7 and 8 in p53 (+/-) mice, long PCR was performed to selectively amplify the wild-type allele of the p53 gene using a Takara LA-PCR kit (Takara Bio, Shiga, Japan) as previously described (22). Due to the localization of mutations, a PCR sense primer for exon 5 was used in combination with antisense primers for exons 7 or 8 (Table I).

Statistical analysis. Data for incidences of tumors were analyzed using Fisher's exact probability test. The survival of each genotype of mice was analyzed with the log-rank test.

\section{Results}

Mortality of mice of each genotype. In Experiment I, 3 untreated and 15 BHP-treated p53 (-/-) mice died before week 
15. The causes of their deaths were mainly the development of lymphomas and sarcomas. In the 20 ppm BHP-treated case, p53 (-/-) mice demonstrated a significantly higher mortality rate than their $533(+/+)$ and $(+/-)$ counterparts $(\mathrm{P}<0.005)$. In the $200 \mathrm{ppm}$ BHP-treated group composed of p53 $(+/+)$ and (+/-) mice, survival rates of both male and female p53 (+/-) mice were remarkably decreased at weeks 12 and later due to hemorrhaging into the abdominal cavity caused by the rupturing of hepatic vascular tumors. On the other hand, all the p53 (+/+) mice survived.

In Experiment II, the mortality of 20 ppm BHP-treated p53 (+/-) mice was significantly higher than in both male and female control p53 (+/-) and BHP-treated p53 (+/+) mice $(\mathrm{P}<0.05)$.

Incidence of HSs. The observed incidences of HSs are summarized in Table II. In the short-term experiment, at 15 weeks HSs were only observed in 20 ppm BHP-treated p53 (-/-) mice, the incidence of this being significantly higher than the lack of it in p53 (+/+) and (+/-) mice of the same dose group $(\mathrm{P}<0.001)$ and untreated $(-/-)$ mice $(\mathrm{P}<0.05)$ (Table II, note a).

In the long-term experiment, the development of HS in BHP-treated p53 (+/-) female mice was significantly increased as compared with BHP-treated (+/+) mice and untreated (+/-) mice $(\mathrm{P}<0.05$ and $<0.005)$ (Table II, note b). Similarly, in male mice, the incidence was higher in BHP-treated p53 (+/-) mice than in treated $(+/+)$ mice, but without statistical significance. Additionally, in both p53 (+/+) and (+/-) mice, the incidences of HS were higher in female mice than in their male counterparts, but statistical significance was again not attained.

Pathological analysis. Macroscopically, HSs sometimes appeared as yellow-white nodules raised above the surface of the liver. However, some cases were detected by histological observation without any gross findings. In two p53 (-/-) mice with systemic invasion of HSs, markedly enlarged livers and spleens were grossly observed.

Microscopically, HSs were composed of large cells with pale eosinophilic cytoplasm and pleomorphic or folded nuclei. Multinucleated giant cells were sometimes present in the neoplastic lesions (Fig. 2A) and, as previously reported, the extramedullary hematopoiesis of erythrocytic series cells was common (23). Vascular invasion of tumor cells was common in the liver, but metastasis to other organs was relatively infrequent. In two p53 (-/-) mice, HS cells were found in multiple organs, including the spleen, lungs and blood vessels. It was possible to classify hepatic HSs into diffuse and nodular types with reference to their proliferation patterns. In the former, HS cells diffusely infiltrated hepatic sinusoids, forming lesions of various sizes in all liver lobes (Fig. 2A). With the latter pattern, HS cells were gathered in multicentric groups (Fig. 2B). The diffuse pattern was observed in 4 of p53 (-/-) mice bearing $\mathrm{HS}$ in the short-term experiment and 2 female $(+/-)$ mice in the long-term experiment. All other lesions were of the nodular pattern. HSs need to be differentiated from lymphomas $(24,25)$. We therefore paid special attention to the differential diagnosis as lymphoma is the most frequent spontaneous tumor in p53 knockout mice $(2,13,14,17)$. Immunohistochemical analyses, using the murine macrophage surface marker F4/80, were used to determine tumor origin. Clusters of positively stained tumor cells were found (Fig. 2C),
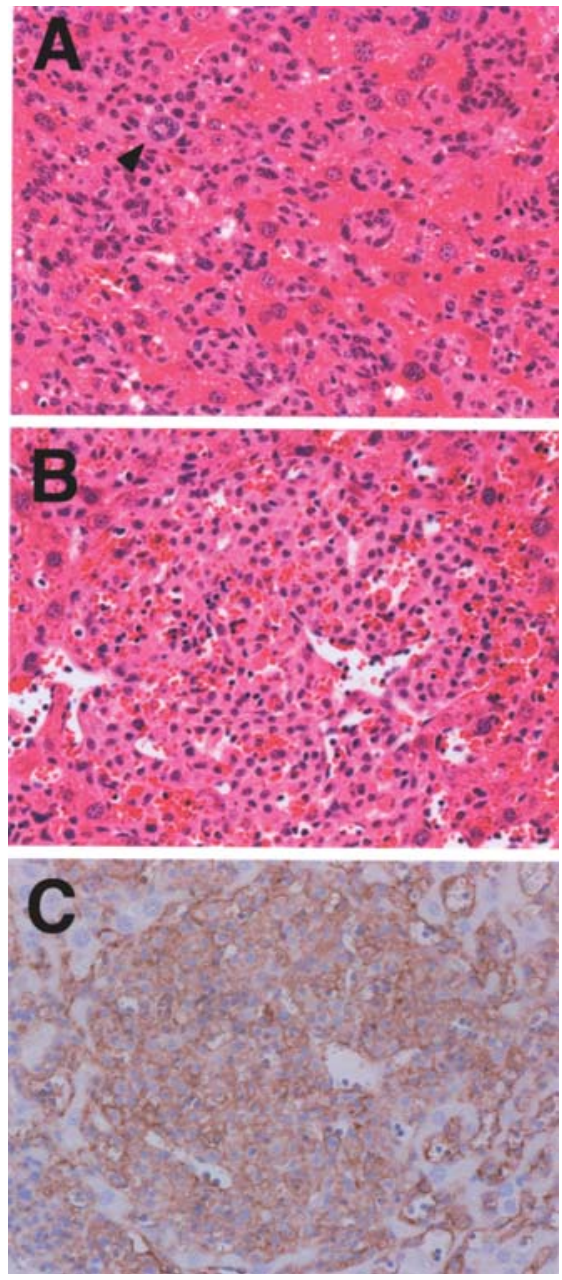

Figure 2. Histopathology of histiocytic sarcomas in p53 knockout mice. (A) Histiocytic sarcoma diffusely infiltrating in sinusoids with multinucleated giant cell formation (arrowheads). H\&E staining. (B and C) Serial sections of a histiocytic sarcoma growing as a nodule. (B) H\&E staining. (C) Immunohistochemistry for F4/80. Original magnification, x200.

although F4/80 yielded various degrees of tumor cell staining within and between tumors. Additionally, HS cells did not react to either of the B- and T-lymphocyte markers, CD45R and $\mathrm{CD} 3$, respectively.

Alterations of the p53 gene in HSs. The $12 \mathrm{HSs}$ which developed in BHP-treated mice, 2 from p53 (+/+) and 10 from $(+/-)$ animals, were subjected to p53 gene analysis. p53 gene mutations were identified in 8 of the $12(66.7 \%)$ lesions. Several mutations were concurrently found in 6 of the HSs and a total of 21 mutations, concentrated in exons 5 and 8 , were detected (Table III). Three (in tumors HS01, HS04 and HS10; all of them with other mutations) were silent and 2 (tumor IDs: HS04 and HS11) were of nonsense type. All the others were missense mutations. Most gave rise to transitions $(19 / 21=90.5 \%)$, with $\mathrm{G}: \mathrm{C} \rightarrow \mathrm{A}: \mathrm{T}$ transitions accounting for $61.9 \%(13 / 21)$ of all the mutations in HSs. In HS04, a multicentric nodular lesion, 2 and 3 mutations were found in exons 5 and 8 , respectively, indicating a heterogeneous cell population. To determine the alleles in which the mutations occurred, LA-PCR was performed to specifically amplify the wild-type allele of the p53 gene. Only one HS (tumor ID: HS01) from p53 (+/-) mice was successfully amplified for 
Table III. p53 gene alterations identified in histiocytic sarcomas.

\begin{tabular}{|c|c|c|c|c|c|c|c|c|c|c|}
\hline \multirow[b]{2}{*}{ No. } & \multirow[b]{2}{*}{$\begin{array}{c}\text { Tumor } \\
\text { ID }\end{array}$} & \multirow[b]{2}{*}{ Sex } & \multirow[b]{2}{*}{$\begin{array}{c}\text { p53 } \\
\text { genotype }\end{array}$} & \multirow[b]{2}{*}{$\begin{array}{c}\text { p53 } \\
\text { LOH }\end{array}$} & \multicolumn{6}{|c|}{ p53 gene mutation } \\
\hline & & & & & Exon & $\begin{array}{l}\text { Mutated } \\
\text { allele }\end{array}$ & Codon & $\begin{array}{c}\text { Nucleotide } \\
\text { change }\end{array}$ & $\begin{array}{l}\text { Amino acid } \\
\text { change }\end{array}$ & Event \\
\hline 1 & HS 03 & $\mathrm{~F}$ & $(+/+)$ & ND & $(-)$ & & & & & \\
\hline \multirow[t]{5}{*}{2} & HS 04 & $\mathrm{~F}$ & $(+/+)$ & ND & 5 & & 153 & $\mathrm{CGT} \rightarrow \mathrm{CAT}$ & Arg $\rightarrow$ His & Transition \\
\hline & & & & & & & 155 & $\mathrm{CGC} \rightarrow \mathrm{CGT}$ & Silent & Transition \\
\hline & & & & & 8 & & 283 & $\mathrm{GAA} \rightarrow \mathrm{TAA}$ & Glu $\rightarrow$ Stop & Transversion \\
\hline & & & & & & & 297 & $\mathrm{CCC} \rightarrow \mathrm{TCC}$ & Pro $\rightarrow$ Ser & Transition \\
\hline & & & & & & & 301 & $\mathrm{GCA} \rightarrow \mathrm{ACA}$ & Ala $\rightarrow$ Thr & Transition \\
\hline \multirow[t]{3}{*}{3} & HS 01 & $\mathrm{M}$ & $(+/-)$ & $(-)$ & 5 & Wild & 179 & $\mathrm{TGC} \rightarrow \mathrm{TGT}$ & Silent & Transition \\
\hline & & & & & 7 & Mutant & 251 & $\mathrm{ATC} \rightarrow \mathrm{ACC}$ & $\mathrm{Ile} \rightarrow \mathrm{Thr}$ & Transition \\
\hline & & & & & 8 & Unknown & 269 & $\mathrm{GTT} \rightarrow \mathrm{GCT}$ & $\mathrm{Val} \rightarrow \mathrm{Ala}$ & Transition \\
\hline 4 & HS 02 & $\mathrm{M}$ & $(+/-)$ & $(-)$ & $(-)$ & & & & & \\
\hline 5 & HS 05 & $\mathrm{~F}$ & $(+/-)$ & $(-)$ & $(-)$ & & & & & \\
\hline 6 & HS 06 & $\mathrm{~F}$ & $(+/-)$ & $(-)$ & 8 & Unknown & 278 & $\mathrm{GAC} \rightarrow \mathrm{GGC}$ & Asp $\rightarrow$ Gly & Transition \\
\hline \multirow[t]{4}{*}{7} & HS 07 & $\mathrm{~F}$ & $(+/-)$ & $(-)$ & 5 & Wild & 152 & $\mathrm{AGC} \rightarrow \mathrm{GGC}$ & Ser $\rightarrow$ Gly & Transition \\
\hline & & & & & & & 172 & $\mathrm{CGC} \rightarrow \mathrm{CAC}$ & $\mathrm{Arg} \rightarrow \mathrm{His}$ & Transition \\
\hline & & & & & 8 & Unknown & 278 & $\mathrm{GAC} \rightarrow \mathrm{GGC}$ & Asp $\rightarrow$ Gly & Transition \\
\hline & & & & & & & 293 & $\mathrm{TGC} \rightarrow \mathrm{CGC}$ & Cys $\rightarrow$ Arg & Transition \\
\hline 8 & HS 08 & $\mathrm{~F}$ & $(+/-)$ & $(-)$ & $(-)$ & & & & & \\
\hline \multirow[t]{3}{*}{9} & HS 09 & $\mathrm{~F}$ & $(+/-)$ & $(-)$ & 5 & Wild & 155 & $\mathrm{CGC} \rightarrow \mathrm{TGC}$ & $\mathrm{Arg} \rightarrow \mathrm{Cys}$ & Transition \\
\hline & & & & & 8 & Unknown & 292 & $\mathrm{CTT} \rightarrow \mathrm{TTT}$ & Leu $\rightarrow$ Phe & Transition \\
\hline & & & & & & & 301 & $\mathrm{GCA} \rightarrow \mathrm{ACA}$ & $\mathrm{Ala} \rightarrow \mathrm{Thr}$ & Transition \\
\hline \multirow[t]{2}{*}{10} & HS 10 & $\mathrm{~F}$ & $(+/-)$ & $(-)$ & 5 & Wild & 153 & $\mathrm{CGT} \rightarrow \mathrm{CAT}$ & Arg $\rightarrow$ His & Transition \\
\hline & & & & & 8 & Unknown & 296 & $\mathrm{CTG} \rightarrow \mathrm{CTA}$ & Silent & Transition \\
\hline \multirow[t]{2}{*}{11} & HS 11 & $\mathrm{~F}$ & $(+/-)$ & $(-)$ & 5 & Wild & 155 & $\mathrm{CGC} \rightarrow \mathrm{TGC}$ & $\mathrm{Arg} \rightarrow \mathrm{Cys}$ & Transition \\
\hline & & & & & 8 & Unknown & 283 & $\mathrm{GAA} \rightarrow \mathrm{TAA}$ & Glu $\rightarrow$ Stop & Transversion \\
\hline 12 & HS 12 & $\mathrm{~F}$ & $(+/-)$ & $(-)$ & 5 & Wild & 149 & $\mathrm{CCA} \rightarrow \mathrm{TCA}$ & Pro $\rightarrow$ Ser & Transition \\
\hline
\end{tabular}

exon 7, and no mutation was identified in the wild-type allele. The other microdissected samples could not be subjected to LA-PCR analysis due to poor preservation of genomic DNA in the paraffin-embedded samples. Primers for the PCRSSCP analysis were used to amplify the wild-type allele of exon 5, and it was revealed that 5 of $7 \mathrm{HSs}$ had missense mutations in exon 5 (tumor IDs: HS07, 09, 10, 11 and 12) of the p53 wild-type allele in p53 (+/-) mice. This indicated the anticipated complete loss of functional p53 protein.

\section{Discussion}

This study clearly demonstrated that p53 knockout mice are highly susceptible to BHP-induction of HS. Thus, in the shortterm experiment, lesions were found in only BHP-treated p53 (-/-) mice, indicating that the complete loss of p53 dramatically accelerated the genesis of HS. The high susceptibility of p53 (-/-) mice was consistent with data for BHPinduced lung and hepatic vascular tumors (20), as well as stomach (21), esophageal (22), tongue (26), colon (27), and urinary bladder (28) carcinogenesis due to other carcinogens.
With long-term treatment of BHP, the significantly greater yield of HSs in p53 (+/-) mice as compared to p53 (+/+) mice again pointed to elevated susceptibility, especially in females. Furthermore, PCR-SSCP and sequencing analysis revealed a high frequency of p53 gene mutations, with the expected complete loss of functional protein in the BHP-induced HS. This is in agreement with earlier reports that the accelerated induction of neoplasms by chemical carcinogens in p53 (+/-) mice is accompanied by the loss of functional p53 through mutational inactivation $(20,22,29,30)$ or the loss of heterozygosity (31). In accordance with Knudson's two-hit hypothesis, the data point to a necessity for a 'second hit' to inactivate the residual normal allele.

To the best of our knowledge, this is the first report to directly demonstrate the relevance of p53 to murine HS development. The tumor suppressor p53 prevents the propagation of genetically damaged cells by the transcriptional regulation of downstream genes (1). As well, increased development of HS has been described in animals genetically engineered for genes downstream of p53, such as p21-deficient and BAX/ ARF double-deficient mice $(8,10)$. Furthermore, Carrasco et al 
demonstrated that p53 expression was frequently repressed, correlating with ARF promoter methylation in human HS (12). The fact that a deficiency of p53 accelerated the development of HSs is in line with our expectations.

$\mathrm{BHP}$ is a multi-organ genotoxic carcinogen which induces various types of tumors in rodents. Through oral administration, it induces lung and hepatic vascular tumors in mice (19). In addition to these tumors (20), though HS induction has not previously been reported in any rodents, including other genetically engineered mice $(32,33)$, BHP unexpectedly induced HSs in p53 knockout mice. Target organs may become altered in genetically engineered mice, reflecting organ-specific sensitivity as indicated for rasH2 mice (34). Thus, p53 knockout mice might not be expected to share the same target organs as wild-type mice because the susceptibility of p53 (+/-) mice to chemical carcinogens is organ-dependent $(20,35,36)$. Ozaki et al reported that, when comparing susceptibilities of rasH2 and p53 (+/-) mice under the same experimental conditions, different types of tumors - lung tumors in rasH2 mice and hepatic hemangiomas in p53 (+/-) mice - were predominantly induced by urethane treatment (37). When genetically engineered mice are used in carcinogenic studies, we must take this characteristic into consideration. Besides the deficiency of p53, the genetic background of p53 knockout mice might partly affect the development of HS. It appears that the spontaneous development of HS is more frequent in the $\mathrm{C} 57 \mathrm{BL} / 6 \mathrm{~J}$ strain than in other common strains. In all cases, the development of HS is infrequent until 18 months of age, but rapidly increases in mice older than 24 months, specifically in C57BL/6J mice $(4,5,7,24)$.

In conclusion, this study clearly shows an elevated susceptibility of nullizygous and heterozygous p53 knockout mice to BHP-induction of HS, with the direct involvement of p53 gene mutations. Our data add to the understanding of the carcinogenic susceptibility of p53 knockout animals and aid in the elucidation of the mechanisms involved in HS development.

\section{Acknowledgements}

We thank Dr Malcolm A. Moore for revision of the scientific English language. This study was supported in part by Grants-in-Aid from the Ministry of Health, Labour and Welfare and the Ministry of Education, Culture, Sports, Science and Technology of Japan.

\section{References}

1. Levine AJ: p53, the cellular gatekeeper for growth and division. Cell 88: 323-331, 1997.

2. Donehower LA, Harvey M, Slagle BL, McArthur MJ, Montgomery CA Jr, Butel JS and Bradley A: Mice deficient for p53 are developmentally normal but susceptible to spontaneous tumours. Nature 356: 215-221, 1992.

3. Storer RD, French JE, Haseman J, Hajian G, Le Grand EK, Long GG, Mixson LA, Ochoa R, Sagartz JE and Soper KA: P53+/- hemizygous knockout mouse: overview of available data. Toxicol Pathol 29 (Suppl.): S30-S50, 2001.

4. Frith $\mathrm{CH}$, Ward JM and Chandra M: The morphology, immunohistochemistry, and incidence of hematopoietic neoplasms in mice and rats. Toxicol Pathol 21: 206-218, 1993.

5. Frith $\mathrm{CH}$ : Histiocytic sarcoma, mouse. In: Hematopoietic System (Monographs on Pathology of Laboratory Animals). Jones TC, Ward JM, Mohr U and Hunt RB (eds). SpringerVerlag, Berlin, pp58-65, 1990.
6. Ward JM and Sheldon W: Expression of mononuclear phagocyte antigens in histiocytic sarcoma of mice. Vet Pathol 30: 560-565, 1993.

7. Frith $\mathrm{CH}$ and Wiley LD: Morphologic classification and correlation of incidence of hyperplastic and neoplastic hematopoietic lesions in mice with age. J Gerontol 36: 534-545, 1981.

8. Martin-Caballero J, Flores JM, Garcia-Palencia P and Serrano M: Tumor susceptibility of p21(Waf1/Cip1)-deficient mice. Cancer Res 61: 6234-6238, 2001

9. McAllister KA, Bennett LM, Houle CD, Ward T, Malphurs J, Collins NK, Cachafeiro C, Haseman J, Goulding EH, Bunch D, Eddy EM, Davis BJ and Wiseman RW: Cancer susceptibility of mice with a homozygous deletion in the $\mathrm{COOH}$-terminal domain of the Brca2 gene. Cancer Res 62: 990-994, 2002.

10. Eischen CM, Rehg JE, Korsmeyer SJ and Cleveland JL: Loss of Bax alters tumor spectrum and tumor numbers in ARF-deficient mice. Cancer Res 62: 2184-2191, 2002.

11. Ward JM, Nikolov NP, Tschetter JR, Kopp JB, Gonzalez FJ, Kimura S and Siegel RM: Progressive glomerulonephritis and histiocytic sarcoma associated with macrophage functional defects in CYP1B1-deficient mice. Toxicol Pathol 32: 710-718, 2004.

12. Carrasco DR, Fenton T, Sukhdeo K, Protopopova M, Enos M, You MJ, Di Vizio D, Nogueira C, Stommel J, Pinkus GS, Fletcher C, Hornick JL, Cavenee WK, Furnari FB and Depinho RA: The PTEN and INK4A/ARF tumor suppressors maintain myelolymphoid homeostasis and cooperate to constrain histiocytic sarcoma development in humans. Cancer Cell 9: 379-390, 2006.

13. Harvey M, McArthur MJ, Montgomery CA Jr, Butel JS, Bradley A and Donehower LA: Spontaneous and carcinogeninduced tumorigenesis in p53-deficient mice. Nat Genet 5: 225-229, 1993.

14. Harvey M, McArthur MJ, Montgomery CA Jr, Bradley A and Donehower LA: Genetic background alters the spectrum of tumors that develop in p53-deficient mice. FASEB J 7: 938-943, 1993.

15. Jacks T, Remington L, Williams BO, Schmitt EM, Halachmi S, Bronson RT and Weinberg RA: Tumor spectrum analysis in p53-mutant mice. Curr Biol 4: 1-7, 1994.

16. Purdie CA, Harrison DJ, Peter A, et al: Tumour incidence, spectrum and ploidy in mice with a large deletion in the p53 gene. Oncogene 9: 603-609, 1994.

17. Donehower LA, Harvey M, Vogel H, McArthur MJ, Montgomery CA Jr, Park SH, Thompson T, Ford RJ and Bradley A: Effects of genetic background on tumorigenesis in p53-deficient mice. Mol Carcinog 14: 16-22, 1995.

18. Kuperwasser C, Hurlbut GD, Kittrell FS, Dickinson ES, Laucirica R, Medina D, Naber SP and Jerry DJ: Development of spontaneous mammary tumors in BALB/c p53 heterozygous mice. A model for Li-Fraumeni syndrome. Am J Pathol 157: 2151-2159, 2000.

19. Konishi Y, Kondo H, Inui S, Denda A, Ikeda T and Kojima K: Organotropic effect of N-bis(2-hydroxypropyl)nitrosamine: production of lung and liver tumors by its oral administration in mice. Jpn J Cancer Res 69: 77-84, 1978.

20. Hirata A, Tsukamoto T, Yamamoto M, Sakai H, Yanai T, Masegi T, Donehower LA and Tatematsu M: Organ-specific susceptibility of p53 knockout mice to N-bis(2-hydroxypropyl) nitrosamine carcinogenesis. Cancer Lett 238: 371-383, 2006.

21. Yamamoto M, Tsukamoto T, Sakai H, Shirai N, Ohgaki H, Furihata C, Donehower LA, Yoshida K and Tatematsu M: p53 knockout mice (-/-) are more susceptible than $(+/-)$ or $(+/+)$ mice to $\mathrm{N}$-methyl-N-nitrosourea stomach carcinogenesis. Carcinogenesis 21: 1891-1897, 2000.

22. Shirai N, Tsukamoto T, Yamamoto M, Iidaka T, Sakai H, Yanai T, Masegi T, Donehower LA and Tatematsu M: Elevated susceptibility of the p53 knockout mouse esophagus to methyl-N-amylnitrosamine carcinogenesis. Carcinogenesis 23: 1541-1547, 2002.

23. Lacroix-Triki M, Lacoste-Collin L, Jozan S, Charlet JP, Caratero C and Courtade M: Histiocytic sarcoma in C57BL/6J female mice is associated with liver hematopoiesis: review of 41 cases. Toxicol Pathol 31: 304-309, 2003.

24. Turusov VS: Histiocytic sarcoma. IARC Sci Publ pp671-680, Lyon, 1994.

25. Frith CH, Ward JM, Harleman JH, Stromberg PC, Halm S, Inoue $\mathrm{T}$ and Wright JA: Hematopoietic system. In: International Classification of Rodent Tumors: The Mouse. Mohr U (ed). Springer-Verlag, Berlin, pp87-138, 2001. 
26. Shirai N, Tsukamoto T, Yamamoto M, Iidaka T, Sakai H, Yanai T, Masegi T, Donehower LA and Tatematsu M: Tongue carcinogenic susceptibility of p53 deficient mice to Methyl-namylnitrosamine. J Toxicol Pathol 15: 209-214, 2002.

27. Sakai H, Tsukamoto T, Yamamoto M, Shirai N, Iidaka T, Hirata A, Yanai T, Masegi T, Donehower LA and Tatematsu M: High susceptibility of nullizygous p53 knockout mice to colorectal tumor induction by 1,2-dimethylhydrazine. J Cancer Res Clin Oncol 129: 335-340, 2003.

28. Yamamoto S, Min W, Lee CC, Salim EI, Wanibuchi H, Sukata $\mathrm{T}$ and Fukushima S: Enhancement of urinary bladder carcinogenesis in nullizygous p53-deficient mice by N-butyl-N(4-hydroxybutyl)nitrosamine. Cancer Lett 135: 137-144, 1999.

29. Mitsumori K, Onodera H, Shimo T, Yasuhara K, Takagi H, Koujitani T, Hirose M, Maruyama C and Wakana S: Rapid induction of uterine tumors with $\mathrm{p} 53$ point mutations in heterozygous p53-deficient CBA mice given a single intraperitoneal administration of N-ethyl-N-nitrosourea. Carcinogenesis 21: 1039-1042, 2000.

30. Nishikawa T, Salim EI, Morimura K, Kaneko M, Ogawa M, Kinoshita A, Osugi H, Kinoshita H and Fukushima S: High susceptibility of p53 knockout mice to esophageal and urinary bladder carcinogenesis induced by $\mathrm{N}, \mathrm{N}$-dibutylnitrosamine. Cancer Lett 194: 45-54, 2003.

31. Dunnick JK, Hardisty JF, Herbert RA, Seely JC, FurediMachacek EM, Foley JF, Lacks GD, Stasiewicz S and French JE: Phenolphthalein induces thymic lymphomas accompanied by loss of the p53 wild type allele in heterozygous p53-deficient (+/-) mice. Toxicol Pathol 25: 533-540, 1997.
32. Tsutsumi M, Masutani M, Nozaki T, Kusuoka O, Tsujiuchi T, Nakagama H, Suzuki H, Konishi Y and Sugimura T: Increased susceptibility of poly(ADP-ribose) polymerase-1 knockout mice to nitrosamine carcinogenicity. Carcinogenesis 22: 1-3, 2001.

33. Okamura M, Moto M, Kashida Y, Machida N and Mitsumori K: Carcinogenic susceptibility to N-bis(2-hydroxypropyl) nitrosamine (DHPN) in rasH2 mice. Toxicol Pathol 32: 474-481, 2004.

34. Mitsumori K, Koizumi H, Nomura T and Yamamoto S: Pathological features of spontaneous and induced tumors in transgenic mice carrying a human prototype c-Ha-ras gene used for sixmonth carcinogenicity studies. Toxicol Pathol 26: 520-531, 1998.

35. Sukata T, Ozaki K, Uwagawa S, Seki T, Wanibuchi H, Yamamoto S, Okuno Y and Fukushima S: Organ-specific, carcinogen-induced increases in cell proliferation in p53deficient mice. Cancer Res 60: 74-79, 2000.

36. Tsukamoto T, Hirata A and Tatematsu M: Susceptibility of heterozygous and nullizygous p53 knockout mice to chemical carcinogenesis: Tissue dependence and role of p53 gene mutations. J Toxicol Pathol 18: 121-134, 2005

37. Ozaki M, Ozaki K, Watanabe T, Uwagawa S, Okuno Y and Shirai T: Susceptibilities of p53 knockout and rasH2 transgenic mice to urethane-induced lung carcinogenesis are inherited from their original strains. Toxicol Pathol 33: 267-271, 2005. 